\title{
Liparis napoensis (Orchidaceae), a new species from Guangxi, China
}

\author{
Lin Li', Shih-Wen Chung², Bo Li³, Song-Jun Zeng', Hai-Fei Yan', Shi-Jin Li' \\ I Key Laboratory of Plant Resources Conservation and Sustainable Utilization, South China Botanical Gar- \\ den, Chinese Academy of Sciences, Guangzhou 510650, Guangdong, China 2 Department of Botany, Taiwan \\ Forestry Research Institute, Taipei, Taiwan 3 College of Agronomy, Jiangxi Agricultural University, Nanchang, \\ 330045, Jiangxi, China
}

Corresponding authors: Hai-Fei Yan (yanhaifei@scib.ac.cn); Shi-Jin Li (lisj@scib.ac.cn)

Academic editor: M. Simo-Droissart | Received 30 November 2018 | Accepted 22 January 2019| Published 15 March 2019

Citation: Li L, Chung S-W, Li B, Zeng S-J, Yan H-F, Li S-J (2019) Liparis napoensis (Orchidaceae), a new species from Guangxi, China. PhytoKeys 119: 31-37. https://doi.org/10.3897/phytokeys.119.32041

\begin{abstract}
Liparis napoensis, a new orchid species belonging to section Cestichis from Guangxi, China is described and illustrated. It occurs in the karst limestone forest. The new species is morphologically similar to L. viridiflora and $L$. somae, but can be readily distinguished by having narrowly oblong-falcate petals; flabellate-quadrate lip distinctly concave at base and emarginate at apex; conspicuously arcuate column with a pair of wedge-shaped wings.
\end{abstract}

\section{Keywords}

Malaxideae, Napo County, orchid, section Cestichis, taxonomy

\section{Introduction}

The genus Liparis L.C. Richard (1817: 21), also known as false twayblade, belongs to the tribe Malaxideae of the subfamily Epidendroideae. It comprises about 320 species with cosmopolitan distribution from the tropics and subtropics to the temperate and alpine regions (Pearce and Cribb 2002, Pridgeon et al. 2005). Since its publica- 
tion, various segregate genera have been proposed such as Alatiliparis Marg. \& Szlach. (2001: 78), Disticholiparis Marg. \& Szlach. (2004: 175), Seidenforchis Marg. (2006: 302) and Platystyliparis Marg. (2007: 35). Molecular phylogenetic studies indicated that Liparis in broad delimitation is polyphyletic (Cameron 2005, Li and Yan 2013). Pridgeon et al. (2005) concluded that Liparis sensu stricto should be restricted to a group of temperate Asian species with the type, L. loeselii (L.) Richard. It is as yet unclear whether the recognition of these splits provides a better taxonomy, thus we opted to maintain Liparis as a broad concept for the present.

As traditionally delimited, Liparis section Cestichis Thouars ex Lindley (1831: 29) is characterised by having coriaceous, non-plicate leaves. They are usually epiphytes with distinct pseudobulbs and occur mainly in tropical Asia. In China, the genus Liparis is represented by about 70 species (Chen et al. 2009), including eight recently described species (see Jin 2011, Wu et al. 2012, Hsu 2013, Li and Yan 2013, Su et al. 2015, Tang et al. 2015). More than half of the Chinese Liparis species (40, about 57\%) belong to section Cestichis.

The limestone karst area is part of a global biodiversity hotspot. Floristic investigations of limestone areas in southwestern Guangxi, China from April 2012 to July 2015, have yielded the discovery of an interesting Liparis species of section Cestichis. Morphologically, this species is superficially similar in appearance to $L$. viridiflora (Blume) Lindley (1831: 31) in vegetative habit, but differs significantly from the latter in the floral morphology. On the other hand, it bears yellowish or whitish flowers somewhat resembling those of L. somae Hayata (1914: 33), a rare species endemic to Taiwan, but several critical details differ. Over the past three years, the living and cultivated specimens were monitored in the field and in the nursery of South China Botanical Garden (SCBG), Chinese Academy of Sciences (CAS). Careful examinations of diagnostic morphological features of similar taxa and literature surveys (Seidenfaden 1976, Comber 1990, Yang 2006, Averyanov 2013, 2015, Tang et al. 2015) indicated that it represents a species new to science and accordingly described herein.

\section{Materials and method}

A total of 450 herbarium specimens of Liparis species in the section Cestichis were examined from herbaria BM, E, HN, IBK, IBSC, K, PE and US (acronyms according to Thiers 2018). The taxonomic status of Liparis napoensis and its close allies were examined by checking the type specimens in these herbaria and online digital image repositories and databases available on JSTOR Global Plants website (http:// plants.jstor.org). Relevant literature, including protologue was consulted. Morphological descriptions and measurements of the putative new species were undertaken based on three living specimens in cultivation (South China Botanical Garden). The specimens were observed and photographed under a stereomicroscope (Olympus MD-90). The conservation status of the new species was evaluated following the guidelines in IUCN (2017). 


\title{
Taxonomic description
}

\author{
Liparis napoensis L.Li, H.F.Yan \& S.J.Li, sp. nov. \\ urn:Isid:ipni.org:names:60478421-2 \\ Figures 1, 2
}

Type. CHINA. Guangxi Zhuang Autonomous Region, Baise City, Napo County, Yongning Village, Jinlongyan Cave, lithophytic on moss in monsoon evergreen broadleaved forest, alt. 830 m, 31 May 2012, L. Li 1001, (holotype, IBSC!).

Diagnosis. Liparis napoensis differs from its closest allies: L. viridiflora and L. somae in the clustered ovoid-cylindrical or narrowly pyriform pseudobulbs, narrowly oblongfalcate petals; a flabellate-quadrate lip with a distinctly concave base, an emarginate apex and erose margins; a conspicuously arcuate column with a pair of wedge-shaped wings.

Description. Lithophytic herbs. Pseudobulbs clustered, ovoid-cylindrical or narrowly pyriform, 5-10 $\mathrm{cm} \times 5-8 \mathrm{~mm}$, attenuate toward apex, base covered with 3-4 fibrous remnant sheaths. Leaves 2, terminal, blade oblanceolate or oblong-spatulate, thin coriaceous, base contracted into a very short petiole less than $1 \mathrm{~cm}$ or subsessile, apex acute and minutely apiculate, $7-12 \times 1.5-2 \mathrm{~cm}$. Inflorescence terminal, often recurved, $15-20 \mathrm{~cm}$, densely racemose, pedunculate; rachis $10-15 \mathrm{~cm}$ with densely arranged numerous flowers; floral bracts linear-lanceolate, 3.5-4 mm, membranous, greenish-white. Flowers resupinate, spreading, 4-4.5 $\mathrm{mm}$ across, white, tinged with pale yellow in the centre; pedicel and ovary 3.5 $-4 \mathrm{~mm}$, pale yellow or greenish-yellow. Dorsal sepal ovate-oblong, margins often revolute, apex obtuse, $2.5-3 \times 0.8-1 \mathrm{~mm}$, translucent white, becoming yellowish towards the base. Lateral sepals obliquely ovate-elliptic, margins often revolute, 2.5-3 $\times 0.8-1 \mathrm{~mm}$, translucent white, becoming yellowish towards the base. Petals narrowly oblong-falcate, margins revolute, $2-2.5 \times 0.3-0.5 \mathrm{~mm}$, translucent white, becoming yellowish towards the base. Lip nearly flabellate-quadrate, $2-2.5 \times 1.5-2 \mathrm{~mm}$, base shallowly concave and distinctly recurved from the middle, indistinctly divided into hypochile and epichile; hypochile ecallose, adaxially slightly thickened and fleshy towards the margins on each side; epichile emarginate, apical margins inconspicuously erose, translucent white, furnished with pale yellow at base. Column terete, conspicuously incurved or arcuate above the middle, apex with 2 short, wedge-shaped wings, with the base slightly dilated, 1.0-1.5 mm long, greenish-white, tinged with pale yellow at base. Stigma concave, subelliptic. Rostellum approximately truncate, apex obtuse, yellowish. Anther terminal, 2-celled, persistent, compressed ovoid, ca. $0.5 \mathrm{~mm}$ long. Pollinia 4, hard, waxy, yellow, ca. $0.3 \mathrm{~mm}$. Capsule obovoid-ellipsoid, ridged, 4-6 $\times 2-3 \mathrm{~mm}$; fruiting pedicel 3-5 mm.

Distribution and habitat. Endemic to Guangxi in China. Lithophytes in rocks crevices where soil or organic matter has accumulated at elevations from ca. $650 \mathrm{~m}$ to $900 \mathrm{~m}$ in karst limestone forest.

Etymology. The epithet "napoensis" is derived from the type locality: Napo County, Guangxi, located at China's southwest border, where the species was discovered.

Phenology. Flowering and fruiting in January-February.

Conservation status. Based on careful field investigations in the past years, this species is rare and only known from the type locality. Plants grow in sparsely scattered 

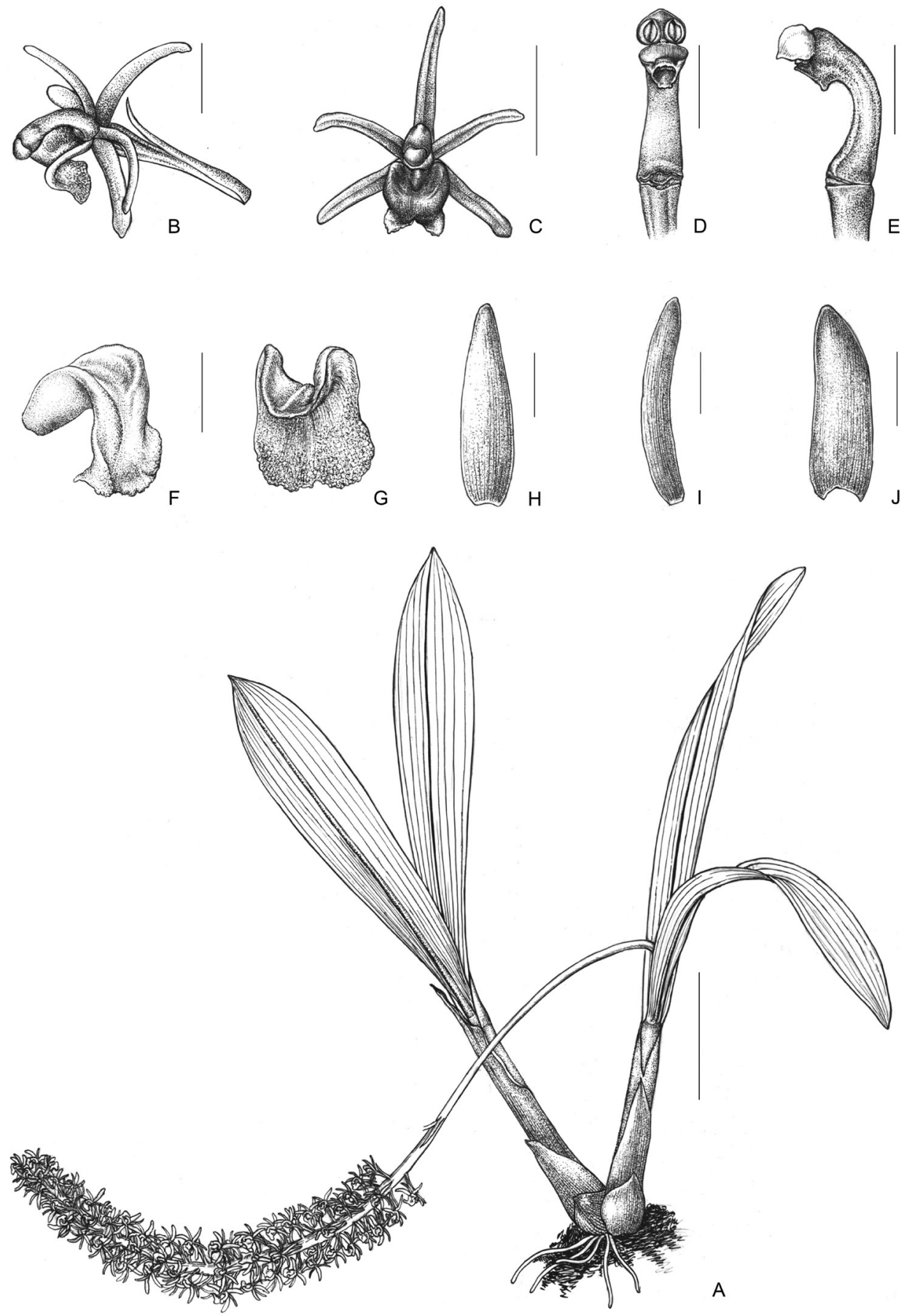

Figure I. Liparis napoensis A Habit in bloom B Flower, lateral view C Flower, front view D Column, ventral view E Column, lateral view F, G Lip H Dorsal sepal I Petal J Lateral sepal. Line drawing by YunXiao Liu. Scale bars: $2.5 \mathrm{~cm}(\mathbf{A}), 2 \mathrm{~mm}$ (B, C), $1 \mathrm{~mm}$ (D-I). 

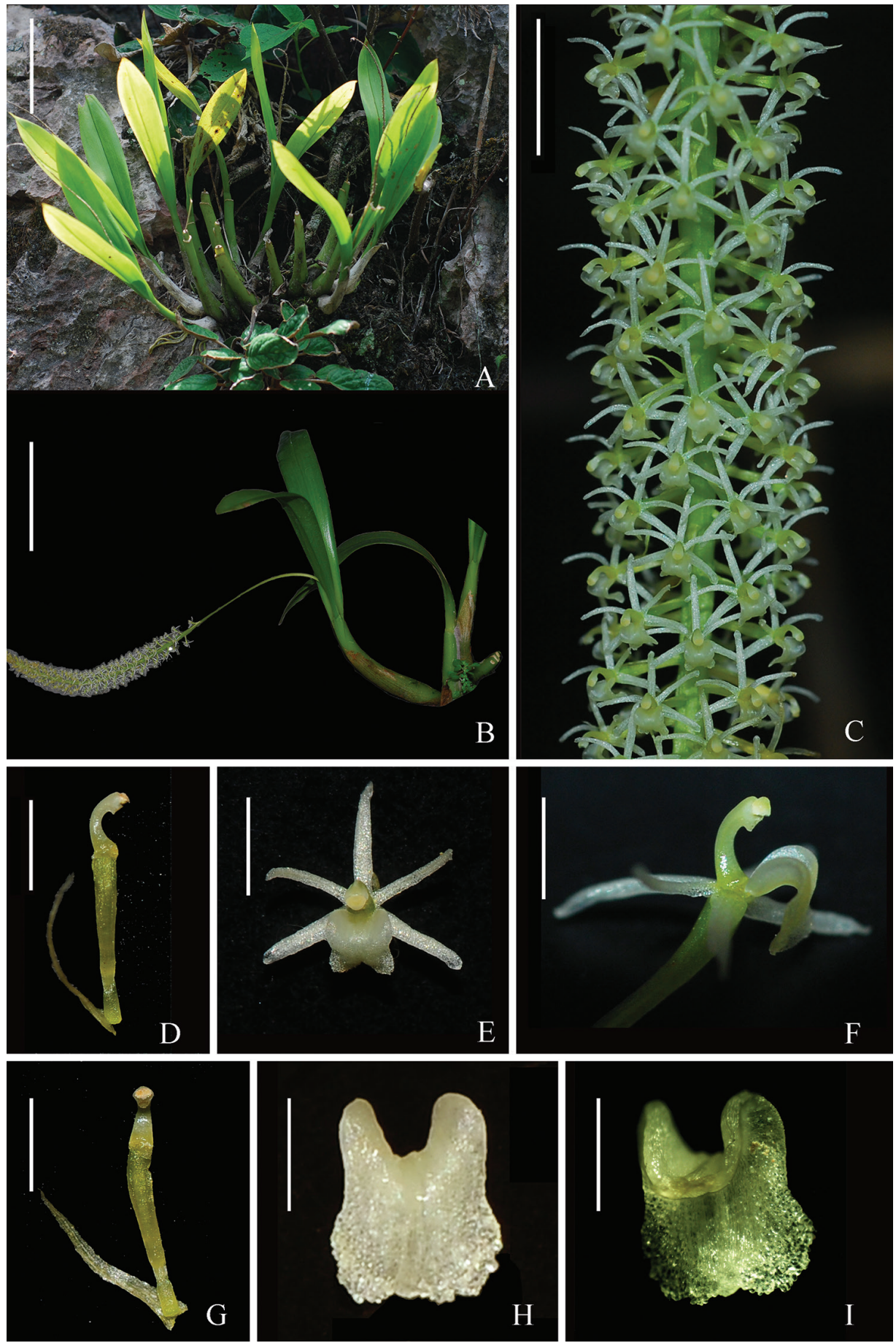

Figure 2. Liparis napoensis A Habitat B A plant in bloom C Inflorescence D Column, lateral view, showing bract $\mathbf{E}$ Flower, frontal view $\mathbf{F}$ Flower, lateral view $\mathbf{G}$ Column, ventral view, showing bract $\mathbf{H}$, I Lip. Scale bars: $5 \mathrm{~cm}(\mathbf{A}-\mathbf{C}), 2 \mathrm{~mm}(\mathbf{D}-\mathbf{G}), 1 \mathrm{~mm}(\mathbf{H}, \mathbf{I})$. 
Table I. Comparison of the diagnostic characters of L. napoensis and its allies.

\begin{tabular}{l|c|c|c}
\hline \multicolumn{1}{c|}{ Characters } & L. napoensis & L. somae & L. viridiflora \\
\hline Growth habit & lithophytes & epiphytes & epiphytes or lithophytes \\
\hline Pseudobulbs & ovoid-cylindrical or narrowly pyriform & ovoid or clavate & elongate-cylindrical \\
\hline Leaves & $\begin{array}{c}\text { oblanceolate or oblong-spatulate, apex } \\
\text { acute and minutely apiculate }\end{array}$ & $\begin{array}{c}\text { oblanceolate or spatulate, } \\
\text { apex acute }\end{array}$ & $\begin{array}{c}\text { linear-oblanceolate, apex } \\
\text { acuminate and apiculate }\end{array}$ \\
\hline Petiole & less than $1 \mathrm{~cm}$ or subsessile & $2-3 \mathrm{~cm}$ & $1-4 \mathrm{~cm}$ \\
\hline Dorsal sepal & ovate-oblong & lanceolate & elliptic-oblong \\
\hline Lateral sepals & obliquely ovate-elliptic & obliquely ovate & ovate-elliptic \\
\hline Petals & narrowly oblong-falcate & linear & narrowly linear \\
\hline Lip & $\begin{array}{c}\text { flabellate-quadrate, base concave, } \\
\text { slightly thickened on each side, } \\
\text { apex emarginate, apical margin } \\
\text { inconspicuously erose }\end{array}$ & $\begin{array}{c}\text { ovate, base slightly } \\
\text { contracted, apex acute, } \\
\text { apical margin slightly } \\
\text { crisped-denticulate }\end{array}$ & $\begin{array}{c}\text { contracted, apex subacute } \\
\text { or mucronate, apical margin } \\
\text { slightly undulate }\end{array}$ \\
\hline Column & $\begin{array}{c}\text { conspicuously arcuate, apex with } \\
2 \text { wedge-shaped wings }\end{array}$ & $\begin{array}{c}\text { slightly arcuate, apex with } \\
\text { 2 obtusely dentate wings }\end{array}$ & $\begin{array}{c}\text { slightly arcuate, apex with } \\
\text { rounded wings }\end{array}$ \\
\hline
\end{tabular}

groups and the known population of two colonies consists of only a few dozen individuals (density less than one plant per $20 \mathrm{~m}^{2}$ ). In addition, the location is not in a protected area and accessible to casual hikers. According to the guidelines for using the IUCN Red List Categories and Criteria (IUCN 2017), the species is categorised as Critically Endangered [CR B2ab(iii)] due to its rarity and the threat of disturbance.

Taxonomic notes. The new species in its general appearance has some superficial similarity with Liparis viridiflora, but the latter differs in longer petioles, narrowly linear petals, ovate-oblong lip with a mucronate tipped apex and a column with rounded wings. It also superficially resembles $L$. somae, but is characterised by having ovoidcylindrical or narrowly pyriform pseudobulbs, a flabellate-quadrate lip with a distinctly concave base and an emarginate apex. A detailed morphological comparison between L. napoensis and its closely related taxa L. viridiflora and L. somae is presented in Table 1 .

\section{Acknowledgments}

We sincerely thank Prof. Cao Ming (Guangxi Institute of Botany, CAS) and Mr. Bi-Ming Nong (Napo Forestry Bureau) for their field help, and Ms. Yun-Xiao Liu (South China Botanical Garden, CAS) for her line drawing image. We are indebted to Dr. Yang ChihKai (National Taiwan University) for his help in the preliminary work of this study. This research was financially supported by grants from the National Natural Science Foundation of China (Nos. 31770215 and 31670193) and Science and Technology Basic Work, Project of the Ministry of Science and Technology, China (No. 2013FY112100).

\section{References}

Averyanov LV (2013) The orchids of Vietnam. Illustrated survey. Part 4. Subfamily Epidendroideae (tribes: Arethuseae and Malaxideae). Turczaninowia 16: 5-163. 
Averyanov LV (2015) New orchids in the flora of Vietnam. Wulfenia 22: 137-188. http:// hoalanvietnam.org/2A_es/4tz/Wulfenia-2015-22-New-Orchids-in-VN.pdf

Cameron KM (2005) Leave it to the leaves: A molecular phylogenetic study of Malaxideae (Epidendroideae, Orchidaceae). American Journal of Botany 92(6): 1025-1032. https:// doi.org/10.3732/ajb.92.6.1025

Chen SC, Ormerod P, Wood JJ (2009) Liparis L.C. Richard. In: Wu ZY, Raven PH, Hong DY (Eds) Flora of China, vol. 25. Science Press, Beijing \& Missouri Botanical Garden Press, St. Louis, 211-228.

Comber JB (1990) Orchids of Java. Bentham-Moxon Trust, Royal Botanic Gardens, Kew, London, $128-141$.

Hayata B (1914) Icones Plantarum Formosanarum nec non et Contributiones ad Floram Formosanam, vol. 4. Bureau of Productive Industries, Taihoku, Taiwan, 27-35.

Hsu TC (2013) Two new species of Liparis (Orchidaceae) from Taiwan. Taiwania 58(1): 1-6.

IUCN (2017) Guidelines for Using the IUCN Red List Categories and Criteria. version 13. Prepared by the Standards and Petitions Subcommittee of the IUCN Species Survival Commission. http://cmsdocs.s3.amazonaws.com/RedListGuidelines.pdf [Accessed 29 November 2018]

Jin XH (2011) Liparis cheniana (Malaxideae: Orchidaceae), a new species from Xizang, China. Annales Botanici Fennici 48(2): 163-165. https://doi.org/10.5735/085.048.0210

Li L, Yan HF (2013) A remarkable new species of Liparis (Orchidaceae) from China and its phylogenetic implications. PLoS One 8(11): e78112. https://doi.org/10.1371/journal. pone. 0078112

Lindley J (1831) The Genera and Species of Orchidaceous Plants. Ridgways, Piccadilly, London, 26-33.

Pearce NR, Cribb PJ (2002) Flora of Bhutan, vol. 3 part 3: The Orchids of Bhutan. Royal Botanic Garden Edinburgh \& Royal Government of Bhutan, 195-212.

Pridgeon AM, Cribb PJ, Chase MW, Rasmussen FN (2005) Genera Orchidacearum vol. 4: Epidendroideae (Part one). Oxford University Press, Oxford, 465-471.

Richard LC (1817) De Orchideis Europaeis Annotations. Belin, Paris, 21, 30, 38. https://doi. org/10.5962/bhl.title.15465

Seidenfaden G (1976) Orchid genera in Thailand IV. Dansk Botanisk Arkiv 31(1): 1-105.

Su YY, Huang YL, Chen LJ, Zhang PW, Liu ZJ, Zhang GQ (2015) Liparis wenshanensis, a new orchid from Yunnan: Evidence from morphology and molecular analyses. Phytotaxa 204(4): 253-264. https://doi.org/10.11646/phytotaxa.204.4.2

Tang GD, Zhang GQ, Hong WJ, Liu ZJ, Zhuang XY (2015) Phylogenetic analysis of Malaxideae (Orchidaceae: Epidendroideae): two new species based on the combined nrDNA ITS and chloroplast matK sequences. Guihaia 35(4): 447-463.

Thiers B (2018) Index Herbariorum: A global directory of public herbaria and associated staff. New York Botanical Garden's Virtual Herbarium. http://sweetgum.nybg.org/ih/ [Accessed September 2018]

Wu L, Huang YS, Yang JC, Xu WB (2012) Liparis damingshanensis (Orchidaceae), a new species from Guangxi, China. Taiwania 57(1): 62-66.

Yang CK (2006) A taxonomic study of Liparis L.C. Rich. (Orchidaceae) of Taiwan. Master Dissertation. National Sun Yat-Sen University, Taipei. 